\title{
Some Introductory Remarks Concerning the Metaphorical use of the Egyptian Words for "Light" and "Heavy"
}

\author{
By Stefan Bojowald*
}

\begin{abstract}
In this contribution, the metaphorical use of the Egyptian words of "light" and "heavy" is investigated. The topic has not been dealt with on a large scale in the past. The present investigation may therefore be considered as the first attempt in this regard. Under this condition, the study can be described as truly innovative. The words "isi" to be light", "wdn" "to be heavy" and "dns'" "to be heavy" will play the most significant role. The words are listed in alphabetical order for clarity. The age details are added in brackets. The evidence covers a spectrum that - depending on the word - ranges from the Middle Kingdom to the Graeco-Roman period. The transferred meanings come from an unexpectedly large number of examples. The poetics of the Egyptian language is so well expressed. The textual basis for the references is formed by several literary genres, among which are temple inscriptions, wisdom texts or hymns. In the broadest sense they can be attributed to the upscale literature, where such occurrences are most likely to be expected. The same metaphorical use of words for "light" and "heavy" can be found in some other oriental languages, for which a limited selection is given. The examples were taken from languages that are spatially and temporally close to the Egyptian. The comparability is thus guaranteed in all cases. The whole phenomenon can thus be viewed from a larger angle.
\end{abstract}

Keywords: Egyptian philology, Egyptian lexicography, metaphorical use of the Egyptian words for "light" and "heavy"

\section{Introduction}

In this contribution, the metaphorical use of the Egyptian words for "heavy" and "light" is explored. The question was tackled in the past rather sporadically. In the scientific literature, the topic has played only a marginal role. The most important pioneering work was done by the authors of the Wörterbuch (for "wdn" cf. WB I, 390, 10-15; for "dnś" cf. WB V, 468, 7-16/469, 2-7). Otherwise, the observations amounted more or less to single remarks (Clère 1949: 42, Gardiner 1923: 16 n. 2/20 n. 11, Griffith 1926: 20 n. 2, Parkinson 2004: 110). However, the scope of the material can be extended considerably. The following examples are able to paint a highly vivid picture of the variability of the Egyptian language. The investigation seems to be absolutely worthwhile before this background. The words "isi" "to be light", "wdn" "to be heavy" and "dnś" "to be heavy" will hereby stand in the centre of the statements. It will become clear that in some cases links can be constructed between these three words. The necessary information about

*Lecturer, University of Bonn, Germany. 
the age of the examples can be taken from the details in the brackets. The Old Kingdom seems to be absent in the present material. The conspicuous phenomenon could have several causes. One reason might have been that the words had only been in use for a while before a transferred meaning could unfold. However, the coincidence of tradition should never be disregarded in such cases. The collection endeavours to be as complete as possible, which may not have been achieved. The examples can at least provide a general overview. The investigation includes every single deviation from the basic meaning. In this work, therefore, a maximalistic approach is chosen, in which the concept of transferred use is handled as freely as possible. In no case can any connection be established between the hieroglyphic writings of the words and their transferred use. The examples were all checked for this possibility. The result was negative each time.

The phenomenon is far from being restricted only to the Egyptian language. The opposite is true, for it can be observed in a number of other oriental idioms. The following selection shall grant a first impression:

The Akkadian language serves as first example, where full attention has to be directed to the root "kabātu". The lexica give for this root the standard meaning "to be/become heavy" (von Soden 1965: 416; Oppenheim 1970: 14), where at the same time the secondary value "to be honoured" (Oppenheim 1970: 16) is hinted at. The nominal base "nakbatu", lit. "heaviness of the army", follows the same path, which must be understood according to von Soden (1947: 78-79) as "tied order". The same phenomenon can be mentioned for the Amorite language, where it is attested very well. The concentration turns there to the root KBD, the etymological relationship of which with the Akkadian "kabātu" is beyond any doubt. The common meaning of this word is "to be heavy", the semantic shade of which could be altered to "to be honourable"(Gelb 1980: 22). The Hebrew language fits in here quite excellently with its root "KBD", the meaning of which can be analyzed in the segments "to be heavy" and "to be honoured/to be important" (Donner 2005: 522). In such cases, the Aramaic language shows a larger degree of individuality, which usually replaces the root "KBD" by the root "YQR" (Millard 1995: 146-147, for the Aramaic root "yqr" cf. Jastrow 2005: 592, Beyer 1994: 358). In contrast to this, the same situation is plainly indicated in the Hittite language (Tischler 1991: 257-261, Puhvel 2007: 43f. Belegstellen and Beal 1992: 488, Anm 1794, Güterbock/ Hoffner 1980-1989: 364-368, Garcia Ramón 2010: 73-89), to name a non-semitic example.

In the question of interest here, the mentioned languages have taken the same intellectual-historical direction. The series could be safely increased by targeted search. However, the present examples are enough to get a first impression. After having reached a certain cultural level, the human mind is inspired according to these examples to the same or at least similar trains of thought. 


\section{The Word "isi" "to be light"}

The root "isi" "to be light" will arouse the first interest in this context. The literal meaning has referred to several areas, under which boats (Wilson 1997: 109) and loads (Wente 1961: 255) can be picked. The figurative sense becomes obvious in the following examples.

The primary meaning could apparently be changed to "to be superficial". Confirmation can be obtained in the passage "isi ib is [śhr (?)]=f" [Barns 1956: 6 (22)], for which the translation "someone light of heart is someone light in his advice" stands to reason. The same interpretation seems to be valid for the passage "nn isi ib dnś śhr h.t" (Middle Kingdom) (Parkinson 2012: 199), for which the translation "no one light of heart is weighty of intent" represents a possible option. The translation is altered by Clére (1949: 41k; cf. Fischer-Elfert 1999: 197) in "il nest pas d'inconsidére qui sache garder caches ils intentions", which seems to be absolutely possible. The passage is in the tale of the "Eloquent Peasant" in which the rhetorical qualities of the title hero are accentuated. The same explanation holds true for the passage "m dd grg iw=k wr.t(i), $m$ isi iw=k dnś.t(i), $m$ dd grg ntk iwśw" (Middle Kingdom) (Parkinson 2012: 162), for which the translation "Speak not falsehood, for you are great! Be not light, for you are weighty! Speak not falsehood, you are the scales!" works best. The word "isi" "to be light" is interpreted by Parkinson as a derogatory quality for the poet. The passage probably means that the addressed person should not make a flippantly or hasty judgement. The German expression "leichtfertig" can be compared in this context, which is also based on the root "leicht". The last quoted texts can serve as a good example for the direct juxtaposition of the two core terms "isi" and "dnś". The two words do not appear so closely behind one another in other sources.

The process could also be inverted in the opposite direction, as can be shown by the use of the word "3ś" "to be quick" in the sense of "to be light" (Hoffmann 1996: 311 n. 1771, Hoffmann 1995: 115).

\section{The Word "wdn" "to be heavy"}

In the second part, metaphorical meanings of the word "wdn" "to be heavy" are taken into account. The literal usage of the word has extended to several fields, such as clouds (Ventker 2012: 153), fruits (Leitz 2012: 261), flooding (Tacke 2001: 116), grain (Egberts 1995: 310) and hippos (Kurth 1998: 54). The metaphorical use is also developed fully in this word, the following examples claiming the most figurative style.

The primary meaning could apparently take on the sense "to be numerous". The same case will reappear in the third part. The fact that the same association can be found in two different words with the meaning "heavy" is noteworthy. The idea seems to be expressed in the passage "ini=f $n=k$ ph śh.t hr pg3.w=f wdn m 'w.t ḥn 'mnmn.t" (Graeco-Roman Time) (E IV, 180, 10-11; for this passage cf. Leitz 2017: 192), for which the translation "he brings you the swamp "bird catch" with its open areas, which is densely packed with small and large cattle" can be 
offered. The passage comes from the accompanying texts to the nome processions in the soubassements of the Graeco-Roman temples. The rich natural and other gifts of the single nomes are brought up there. The same explanation applies to the next two examples. The interpretation as such holds true for the passage "ini $=\mathrm{f} n=k$ ph śh.t hr h'.t=f wr.ti m hmś.w m ng wdn.ti m k3.w ḥn 'id.wt" (Graeco-Roman Time) (Médamoud= FIFAO 3, 2, Nr. 173, for this passage cf. Leitz 2017: 192), which can be translated most easily by "he brings you the swamp "bird catch" with its hill country, which is big with opened corn ears and densely packed with bulls and cows". The same aspect plays a role in the passage "ini=f $n=k$ ph śh.t hr h.t $\mathrm{f}=\mathrm{f}$ wdn m '.wt ḥn' mnmn.t" (Graeco-Roman Time) (D XII, 68, 7-8; for this passage cf. Leitz 2014a: 89; Leitz 2017: 192), for which the translation "he brings you the swamp "bird catch" with its products, which is densely packed with small and large cattle" seems to be useful. The transfer process from "to be heavy" to "to be numerous" is difficult to explain. The interpretation that for the Egyptians more hooves of larger herds put more pressure on the ground must remain speculative.

The primary meaning could apparently be modified to "to be swollen". The passage "d $3 \underline{\mathrm{d}} 3=\mathrm{f}$ wdn $\mathrm{m}-{ }^{-} \mathrm{t} 3 \mathrm{w}$ n $3 \mathrm{tf}$ nti $\mathrm{m} \underline{\mathrm{d}} 3 \underline{\mathrm{d}} 3=\mathrm{f}^{\text {" (Graeco-Roman Time) (Leitz }}$ 2017: 338) shows the influence of this idea, for which the translation "his head was swollen from the heat of the Atef-crown, which was on his head." can be given. In the passage, the god Osiris and his head ornate are hinted at. The explanation can probably be found in the fact that the swollen head, viewed from the outside, expands in size und thus becomes more massive.

The basic meaning could apparently undergo a transformation process to "to be thick". The verification for this can be detected in the passage "ir m33=i [ih hr nf]w wnn=f ir.ti=f(i) śtp rmi.w=f wdn.w" (Middle Kingdom) (Guth 2018: 127), for which the translation "if I see [a cow, which is suffering from the nfw (?)illness], its eyes dripping and its tears being heavy" seems to be appropriate. The passage is to be found in the context of a veterinary treatise. The "heavy tears" are seen by Guth as thick outflow of the eyes, following a proposal of Lord (Lord 2011: 103). The explanation pertains probably to the belief that viscous substances fall more easily to the ground by the larger gravity.

\section{The Word "dnś" "to be heavy"}

The third part is devoted to the study of the figurative meanings of the word "dnś" "to be heavy". The literal use of the word covers a wider range, under which grain (Leitz 2017: 188), horse team (Fischer-Elfert 1986a: 103), corpse (Leitz 2014b: 138/468) and grapes (Kurth 2004: 523) can be singled out. The metaphorical use is also strongly developed in its case.

The primary meaning could apparently alternate to "to be burdensome". The respective sense builds the quintessential of the passage "dnś rnp.t $r$ sn.w=ś" (First Intermediate Period) (Gardiner 1969: 101-102), for which the translation "one year is more burdensome than the other" makes a good impression. The passage can be found in the "Admonitions of Ipuwer" which responded to the collapse of the Old 
Kingdom. The same attitude can be detected in the German word "beschwerlich", which depends semantically on the word "schwer sein".

The basic meaning could seemingly also be modified to "to be reticent". The passage "ntk dnś śhr.w h3n wšb.t bwt=k hnw-didi dr mśii.t=k" (New Kingdom) (Gardiner 1937: 114, Caminos 1954: 421, Tacke 2001: 117) tests this idea, for which the translation "You are one reticent in counsel, one who weighs (his) answer, your abomination is obscene talk since your birth" is a good solution. The words praise the good character traits of the person referred to. The meaning "to be heavy" may perhaps even go as far as "to be profound" in a figurative sense.

The primary meaning could apparently alternate to "to be heavily loaded". The idea dominates obviously the passage "imn.tiw i3b.tiw dnś hr ih.wt=śn" (Graeco-Roman Period) (Kalabscha I, 4; for this passage cf. Nagel 2019: 148), for which the translation "the western ones und the eastern ones, heavily loaded with their products" seems to be a good choice. In this passage, tribute bearers from the cardinal points of the earth are described. The statement is literally not to understand. The heaviness really belongs to the burden on the wearer' $s$ shoulders and has been referred figuratively here to the people themselves. The author of the text has taken a great deal of poetic interest here.

The basic meaning could apparently also change in "to be earnest". The passage "dnś imi=k w3i r šfii.t" (Middle Kingdom) (Helck 1970: 131; for this passage see Jäger 2004: 151) is here fore of high significance, which seems to call for the translation "Be earnest! You should not be far from dignity". The words are spoken by a teacher to his pupil, being understood as an appeal to the right discipline.

The primary meaning could also be shifted to "to be dull". The idea is manifested in the passage "kri šri ' 3 wsi ib=k, bw śdm=k iw=i md.t. dnś ib=k r mnw '3, n mh $100 \mathrm{~m}$ hii wmt 10, iw=f grh $\mathrm{r} \mathrm{r}$-' 3tp=f" (New Kingdom) (Gardiner 1937: 101, Caminos 1954: 377, Tacke 2001: 88), for which the translation "Young fellow, how conceited you are! You do not hearken when I speak. Your heart is heavier than a great monument of a hundred cubits in height and ten in thickness, which is finished and ready to be loaded" is a good choice. The inflexibility of the pupil is expressed by the comparison with the stone object very clearly.

The primary meaning could apparently receive the secondary sense "to be restrained". The idea is relevant for the understanding of the passage "dnś tw $\mathrm{m}$ ḥ3.ti=k śmn ḥ3.ti=k, $m$ ir iri ḥm m nś.t=k" (New Kingdom) (Grumach 1972: 125), for which the translation "Pull back in your heart, strengthen your heart, do not steer with your tongue" is quite accurate. The example comes from a wisdom text, in which the teacher educates the student about the right way of life. The interpretation of "dnś" as "to contain/to be reserved" has been suggested already by Grumach. The same notion is important for the correct understanding of the passage "dnś r ib iw=tw (ḥr) mdw.t, m-iri tpi-r3 [m w]šb.t=k ḥr nḍnd ih.t, hpr i$\mathrm{dd}=\mathrm{k}$ nb mnh" (New Kingdom) (Quack 1994: 87), for which the translation "Be cautious, if one speaks. Do not give hasty answers in the council, so everything you say becomes good" seems to be appropriate. The passage comes from another wisdom text that gives the addressee good advices for the right behaviour in the 
public. The statements differ only by the two different heart names, but that does not change their content ${ }^{1}$.

The primary meaning could apparently be developed further to "to be important". The very sense can be demonstrated in the passage "m-ir pšn ḥ.ti=k r nś=k hpr śhr.w=k nb m 'r, hpr dnś.tw m-b3h t3 kwi iw=k wd3.tw m dr.t ntr" (New Kingdom) (Grumach 1972: 84 ), for which the translation "Do not divide your heart from your tongue, so all plans of you become successful. You will be important by the people, while you are sane in the hand of the god" seems to be realistic. The passage is embedded in a famous wisdom text. The message has to be analyzed according to Grumach (1972: 86) that the tongue should not be robbed from the refreshing power of the heart. The passage "dnś $=\mathrm{k}$ rn n s3=k iri mrr.t=k" (New Kingdom) (Gülden 2001: 37) evidently requires the same explanation, for which the translation "may you make [the name] of your son important who does what you want" best fulfils its purpose. The words can be found in a prayer for the king. The German language also mimics the connection between "gewichtig" and "wichtig".

The primary meaning could apparently be expanded to "to be annoying". The passage "iw-mś ḥm.wt nb.wt śhm m r3.w=śn mdw ḥn.wt dnś pw r b3k.w" (First Intermediate Period) (Helck 1995: 21) is here fore a case in point, for which the translation "Lo, all female slaves are impudent with their mouth, but the speech of the mistresses is annoying for the servants" can be proposed. The statement is probably to be understood as meaning that the speech of the mistresses is hard to bear for the servants. The concept of heaviness has therefore been raised to a psychological level. The motive has to be seen against the background of the reversal of conditions in times of political anarchy.

The primary meaning could apparently be devolved to "to be weighty". The striking proof can be found in the passage "mdw $\{\mathrm{t}\} \mathrm{r}$-tr=f wšb $\mathrm{r}$ nw=f šwi $\mathrm{m}$ h3h r3 dnś r3" (Late Period) (Kuhlmann/Schenkel 1983: 74 and Taf. 25), for which the translation "who speaks, when it is time, who answers at the right moment, who is free from hasty mouth, with weighty speech" offers a good solution. The words are chosen to praise the qualities of the honourable tomb owner. The German expression "rhetorisches Schwergewicht" can be mentioned for comparison. The statement is probably to be explained that the man's speech has also moral weight. The meaning "to be weighty" of "dnś" is suggested by FischerElfert (1999: 196) to be changed to "to be hidden", who interprets it as alternative for "imn" und "hrp" in comparable texts. The abstraction could, however, go a little too far, because the famous principle "varietas delectat" is neglected totally.

The primary meaning was apparently used to reproduce numerical large quantities. The same case could be found in the second paragraph about "wdn". The example here seems to be the only case for an overlap of the transferred use of the two words. The similarities between these two words seem to be limited - beyond the semantic aspect - to this point. The relevant pattern pervades the passage "ih.t w3w3.t dnś.ti r š $\mathrm{n}$ wd̆b m ś.t-wr.t-n.t-ḥr-3h.ti" (Graeco-Roman Time) (Baumann 2018: 284), for which the translation "The products of Wawat may be in "Great-

\footnotetext{
${ }^{1}$ For the relationship between "ib"-heart and "h3.ti"-heart cf. von Deines/Westendorf 1961: 3544
} 
Seat-of-Harachte" more numerous than the sand of the shore" seems to be recommendable. The content goes into the overabundance of the tributes from southern Nubia. In the Egyptian language, the sand served generally as synonym for countless lots of humans or things. The same idea is reflected in the passage "ini=i $\mathrm{n}=\mathrm{k}$... śh.t dnś m k3.w id.wt" (Graeco-Roman Time) (Opet I, 286 rechts; for this passage cf. Leitz 2017: 192), for which the translation "I bring you ... the swamp "Bird catch", which is densely packed with bulls and cows" seems to be plausible. In these words, the positive aspects of each region of Egypt are described. The same factor shines through in the passage "ini=f $[\mathrm{n}=\mathrm{k}]$ ph śh.t hr m3w.t=f dnś $\mathrm{m}$ k3.w ḥn' id.wt" (Graeco-Roman Time) (FIFAO 3/2, Nr. 83 6; E V, 113, 11; for this passage cf. Leitz 2014a: 89, Leitz 2014b: 84, Leitz 2017: 192) for which the translation "He brings [you] the swamp area "Bird catch" with its new land, which is densely packed with bulls and cows" serves well. The explanation proves equally suitable in the passage " $\operatorname{rdi}(=\mathrm{i}) \mathrm{n}=\mathrm{k}$ šśr.w wr.ti $\mathrm{m} \mathrm{nmt}=\mathrm{k}$, mhtm(.t) dnś.ti $\mathrm{m}$ k3.w" (Graeco-Roman Time) (Kurth 2004: 604), for which the translation" (I) give you that the animals for slaughter are numerous in your slaughter-house and the bulls are in abundance in your cowshed" is objectively most correct. The problem of the development from "to be heavy" to "to be numerous" was already tried to solve in the second part.

The primary meaning could apparently evolve to "to be enormous" The sense adheres obviously to the passage "dnś b3.w=ś r dw n bi3" (Assmann 1999: Anhang Nr. 2) for which the translation "More enormous is her anger than a mountain of ore" looks promising. The words are spoken to characterize the almighty and terrifying goddess Toeris. In this example, the concept of heaviness is imposed on an abstract entity.

The primary meaning could apparently be amended to "to be cumbersome". The aspect shines through in the passage "sh3 qd.wt m ś.t m3 .t [....] dnś dr.t... dw ... ndh...iśmr" (New Kingdom) (Fischer-Elfert 1997: 57), for which the translation "The pre-painter in the place of Maat $[. .$.$] with weighing hand... \underline{\mathrm{d} w}$ ... ndh-mineral...iśmr-mineral" serves pretty well. The small piece may perhaps be attributed to the text type of the so-called "Characteristic". According to Fischer-Elfert, the fragment has to be interpreted to the effect that it alludes to the strenuous work of the pre-painter by the registration of the afterwards named minerals. The feeling of being heavy may also be caused by a certain tiredness.

The semantic spectrum of the word could apparently be expanded to "to be high rising". The message is clearly in the mind of the author of the passage "H'pi im=k wśf, s3w dnś=k" (New Kingdom) (Fischer-Elfert 1986b: 59), for which the translation "Hapi, do not be to slow, but do not also be to high" can be given. The quotation is taken from a lesser known Nile hymn. According to Westendorf (1981: 80), the expression aims at the overabundant water masses on the inundated land. The pressure of the water on the square centimetre of earth certainly played the decisive role. 
Vol. 7, No. $1 \quad$ Bojowald: Some Introductory Remarks Concerning the Metaphorical...

\section{Conclusion}

In conclusion, it can be stated that the Egyptian words for "light" and "heavy" were metaphorically very productive. The evidence is limited for "isi" on the Middle Kingdom, while it dates for "wdn" and " dnś" from the First Intermediate Period/Middle Kingdom to the Graeco-Roman time (Table 1). The new creations give a surprising diverse picture, such that no homogenous system can be found. The possibility that in some cases ad-hoc formations exist must therefore be calculated with.

Table 1. Literal and Metaphorical Meanings

\begin{tabular}{|l|l|l|}
\hline & Literal meaning & metaphorical meaning \\
\hline isi & to be light & to be superficial \\
\hline wdn & to be heavy & to be numerous \\
\hline & & to be swollen \\
\hline & & to be thick \\
\hline dnś & to be heavy & to be burdensome \\
\hline & & to be reticent \\
\hline & & to be loaded \\
\hline & & to be earnest \\
\hline & & to be dull \\
\hline & & to be restrained \\
\hline & & to be important \\
\hline & & to be annoying \\
\hline & & to be weighty \\
\hline & & to be numerous \\
\hline & & to be enormous \\
\hline & & to be cumbersome \\
\hline & & to be high rising \\
\hline
\end{tabular}

\section{References}

Assmann J (1999) Ägyptische Hymnen und Gebete (Egyptian hymns and prayers). Fribourg/Göttingen: Universitätsverlag/Vandenhoeck Ruprecht.

Barns JW (1956) Five ramesseum papyri. Oxford: Griffith Institute.

Baumann St (2018) Schatzkammern, Ihre Dekoration und Raumkonzeption in ägyptischen Tempeln der griechisch-römischen Zeit, Teil 1 (Treasure Chambers, Your Decoration and Spatial Conception in Egyptian Temples of the Greco-Roman Period, Part 1). Studien zur spätägyptischen Religion 19. Wiesbaden: Harrassowitz Verlag.

Beal R (1992) The Organisation of the Hittite Military. Texte der Hethiter 20, Heidelberg. Beyer K (1994) Die aramäischen Texte vom Toten Meer, samt Inschriften aus Palästina, dem Testament Levis aus der Kairoer Genisa, der Fastenrolle und der alten talmudischen Zitaten, Aramaistische Einleitung, Text, Übersetzung, Deutung, Grammatik, Wörterbuch, Deutsch-aramäische Wortliste, Register, Ergänzungsband (The Aramaic texts from the Dead Sea, including inscriptions from Palestine, the Testament Levis from the Cairo Genisa, the Lent roll and the ancient Talmudic 
quotations, Aramaistic introduction, text, translation, interpretation, grammar, dictionary, German Aramaic word list, register, supplementary volume). Göttingen.

Caminos RA (1954) Late-Egyptian Miscellanies. Brown Egyptological Studies I, London: Oxford University Press.

Clère JJ (1949) L'expression dnc mhw.t des autobiographies égyptiennes. Journal of Egyptian Archaeology 35: 38-42.

Donner H (Hrsg.) (2005) Wilhelm Gesenius, Hebräisches und Aramäisches Handwörterbuch über das Alte Testament (Wilhelm Gesenius, Hebrew and Aramaic Hand Dictionary on the Old Testament). Berlin: Springer.

Egberts A (1995) In quest of meaning, a study of the ancient Egyptian rites of consecrating the meret-chests and driving the calves. Egyptologische Uitgaven 8, Leuven: Peeters Publishers.

Fischer-Elfert H-W (1986a) Die satirische Streitschrift des Papyrus Anastasi I (The satirical polemic of the papyrus Anastasi I). Ägyptologische Abhandlungen 44, Wiesbaden.

Fischer-Elfert H-W (1986b) Literarische Ostraka der Ramessidenzeit in Übersetzung (Literary ostraca of the Ramesside period in translation). Kleine Ägyptische Texte 9, Wiesbaden.

Fischer-Elfert H-W (1997) Lesefunde im literarischen Steinbruch von Deir el-Medineh (Readings in the literary quarry of Deir el-Medineh). Kleine Ägyptische Texte 12, Wiesbaden.

Fischer-Elfert H-W (1999) Die Lehre eines Mannes für seinen Sohn, Eine Etappe auf dem "Gottesweg" des loyalen und solidarischen Beamten des Mittleren Reiches (The teaching of a man for his son, A stage on the "Gotthesweg" of the loyal and solidary officials of the Middle Kingdom). Ägyptologische Abhandlungen 60, Wiesbaden.

Garcia Ramón JL (2010) Hethitisch nakki- und homerisch phéristos: avestisch bairiSta-, homerisch phérteros, phértatos. In J Klinger, E Rieken, Chr. Rüster (Eds.), Investigationes Anatolicae, Gedenkschrift für Erich Neu, pp. 73-89. Studien zu den Bogazköy-Texten Band 52, Wiesbaden.

Gardiner AH (1923) The eloquent peasant. Journal of Egyptian Archaeology 9.

Gardiner AH (1937) Late-Egyptian miscellanies. Bibliotheca Aegyptiaca VII, Bruxelles.

Gardiner AH (1969) The Admonitions of an Egyptian sage from a Hieratic Papyrus in Leiden (Pap. Leiden 344 recto). Hildesheim.

Gelb JJ (1980) Computer-Aided Analysis of Amorite. Assyriological Studies no. 21, Chicago.

Griffith F (1926) The teaching of Amenophis, The son of Kanakht. Papyrus B.M. 10474. Journal of Egyptian Archaeology 12: 191-231.

Grumach I (1972) Untersuchungen zur Lebenslehre des Amenope (Studies on the life of Amenope). Münchner Ägyptologische Studien 23. München-Berlin.

Gülden SA (2001) Die hieratischen Texte des P. Berlin 3049. Kleine Ägyptische Texte 13, Wiesbaden.

Güterbock HJ, Hoffner Jr HA (1980-1989) The Hittite dictionary of the Oriental Institute of the University of Chicago, vol L-N. Chicago: The Oriental Institute of the University of Chicago.

Guth S (2018) Hirtenbilder, Untersuchungen zur kulturimmanenten Sicht auf eine altägyptische Personengruppe (Shepherds, studies on the culture-immanent view of an ancient Egyptian group of people). Beihefte Studien zur altägyptischen Kultur 21, Hamburg: BUSKE.

Helck W (1970) Die Lehre des dwA-xtii, Teil II (The Doctrine of the dwA-xtii, Part II). Kleine Ägyptische Texte 3, Wiesbaden. 
Vol. 7, No. $1 \quad$ Bojowald: Some Introductory Remarks Concerning the Metaphorical...

Helck W (1995) Die "Admonitions" Pap. Leiden I 344 recto (The "Admonitions" Pap. Leiden I 344 recto). Kleine Ägyptische Texte 11. Wiesbaden.

Hoffmann Fr. (1995) Ägypter und Amazonen, Neubearbeitung zweier demotischer Papyri, P. Vindob.D 6165 und P. Vindob. D 6165 A (Egyptians and Amazons, revision of two demotic Pa.pyri, P. Vindob.D 6165 and P. Vindob. D 6165 A). Mitteilungen aus der Papyrussammlung Erzherzog Rainer Neue Serie, Band 24. Wien.

Hoffmann Fr. (1996) Der Kampf um den Panzer des Inaros, Studien zum P. Krall und seiner Stellung innerhalb des Inaros-Petubastis-Zyklus (The battle for the tank of Inaros, studies of P. Krall and his position within the Inaros-Petubastis cycle). Mitteilungen aus der Papyrussammlung Erzherzog Rainer Neue Serie, Band 26. Wien.

Jäger St (2004) Altägyptische Berufstypologien (Ancient Egyptian occupation typologies). Lingua Aegyptia Studia Monographica 44. Göttingen.

Jastrow M (2005) A dictionary of the Targumim, the Talmud Babli and Yerushalmi, and the Midrashic literature, 2 volumes in 1. Brooklyn.

Kuhlmann K, Schenkel W (1983) Das Grab des Ibi, Obergutsverwalters der Gottesgemahlin des Amun, band I (The Tomb of Ibi, Chief Administrator of the Divine Wife of Amun, vol. I). Mainz: Zabern.

Kurth D (1998) Die inschriften des tempels von Edfu, band 1: Edfou VIII (The inscriptions of the temple of Edfu, volume 1: Edfou VIII). Wiesbaden: Harrassowitz Verlag.

Kurth D (2004) Edfu VII, Die inschriften des tempels von Edfu, Abteilung I, übersetzungen, band 2 (Edfu VII, The inscriptions of the temple of Edfu, division I, translations, volume 2). Wiesbaden: Harrassowitz Verlag.

Leitz C (2012) Geographisch-osirianische Prozessionen aus Philae, Dendara und Athribis, Soubassementstudien II (Geographical-Osirian processions from Philae, Dendara and Athribis, Soubassementstudien II). Studien zur spätägyptischen Religion 8. Wiesbaden: Harrassowitz.

Leitz C (2014a) Geographische Soubassementtexte aus griechisch-römischer Zeit: Eine Hauptquelle altägyptischer Kulttopographie (Geographical subbasement texts from the Greco-Roman period: A main source of ancient Egyptian cult topography). In A Rickert, B Ventker (Eds.), Altägyptische Enzyklopädien, Die Soubassements in den Tempeln der griechisch-römischen Zeit, Soubassementstudien I, vol. 1. (Ancient Egyptian Encyclopedias, The Soubassements in the Temples of the Greco-Roman Period, Soubassementstudien I, vol. 1). Studien zur spätägyptischen Religion 7, Wiesbaden.

Leitz C (2014b) Die Gaumonographie in Edfu und ihre Papyrusvariante, Ein überregionaler Kanon kultischen Wissens im spätzeitlichen Ägypten, Zeichnungen von Mareike Wagner, Soubassementstudien III, Teil 1: Text (The gaumonography in Edfu and its papyrus variant, A supraregional canon of cultic knowledge in late Egypt, Drawings by Mareike Wagner, Soubassementstudien III, Part 1: Text). Studien zur spätägyptischen Religion 9. Wiesbaden.

Leitz C (2017) Die regionale mythologie Ägyptens nach Ausweis der geographischen Prozessionen in den späten Tempeln, Soubassementstudien IV, Teil 1: Text (The Regional mythology of Egypt after evidence of geographic processions in the late temples, Soubassement Studies IV, Part 1: Text). Studien zur spätägyptischen Religion 10. Wiesbaden.

Lord C (2011) The veterinary papyrus of Kahun. In Current research in Egyptology 2009: proceedings of the tenth annual symposium, University of Liverpool 2009, edited by $\mathrm{J}$ Corbelli, D Boatright, C Malleson, pp. 99-105. Oxford: Oxbow Books. 
Millard A (1995) Cognates can be deceptive: Some Aramaic distinctives. In MJ Geller, JC Greenfield, MP Weitzman (Eds.), Studia Aramaica, pp. 145-149. New York: Oxford University Press.

Nagel S (2019) Isis im Römischen Reich, Teil 1: Die Göttin im griechisch-römischen Ägypten, Philippika, Altertumswissenschaftiche Abhandlungen (Isis in the Roman Empire, part 1: The goddess in Greco-Roman Egypt, Philippica, Ancient studies treatises). Contributions to the Study of Ancient World Cultures 109, Wiesbaden: Harrassowitz.

Oppenheim AL (Ed.) (1970) The Assyrian dictionary, vol. 8. Chicago: Oriental Institute.

Parkinson RB (2004) The discourse of the Fowler: Papyrus Butler Verso (P.BM EA 10274). Journal of Egyptian Archaeology 90: 81-111.

Parkinson RB (2012) The tale of the eloquent peasant: A reader's commentary. Lingua Aegyptia Studia Monographica 10, Hamburg: Widmaier Verlag.

Puhvel J (2007) Hittite etymological dictionary, vol. 7. Words beginning with N, Trends in Linguistic Documentation 26. Berlin-New York: De Gruynter Mouton.

Quack J Fr. (1994) Die Lehren des Ani, Ein neuägyptischer Weisheitstext in seinem kulturellen Umfeld (The teachings of Ani, A New Egyptian wisdom text in its cultural environment). Freiburg, Switzerland/Göttingen, Germany: Universitätsverlag/ Vandenhoeck Ruprecht.

von Deines H, Westendorf W (1961) Wörterbuch der Medizinischen Texte, Erste Hälfte $(A-r)[$ Dictionary of Medical Texts, First Half $(A-r)]$. Grundriss der Medizin der alten Ägypter VII 1, Berlin.

von Soden W (1947) Zum akkadischen Wörterbuch, 6-14 (To the Accadian Dictionary, 6-14). Orientalia 16(1): 66-84.

von Soden W (1965) Akkadisches handwörterbuch, band I, A-L (Akkadian dictionary, volume I, $A-L)$. Wiesbaden: Harrassowitz.

Tacke N (2001) Verspunkte als Gliederungsmittel in ramessidischen Schülerhandschriften (Verspunkte as a structure in Ramessian pupil manuscripts). Studien zur Archäologie und Geschichte Altägyptens 22. Heidelberg: Heidelberg Orientverlag.

Tischler J (1991) Hethitisches etymologisches Glossar, Mit Beiträgen von Günter Neumann, Teil II, Lieferung 7: N (Hittite etymological glossary, with contributions by Günter Neumann, part II, delivery 7: N). Innsbrucker Beiträge zur Sprachwissenschaft 20, Teil II, Innsbruck: Institut fur Sprachwissenschaft.

Ventker B (2012) Der Starke auf dem Dach, Funktion und Bedeutung der löwengestaltigen Wasserspeier im alten Ägypten (The strong on the roof, function and meaning of the lion-shaped gargoyles in the old Egypt). Studien zur spätägyptischen Religion 6. Wiesbaden: Harrassowitz.

Wente EF (1961) A letter of complaint to the Vizier to. Journal of Near Eastern Studies 20(4): 252-257.

Westendorf W (1981) Beiträge aus und zu den medizinischen Texten, V. Der "lastende" Nil und "die Seuche des Jahres" (Contributions from and to the Medical Texts, V. The "Lasting" Nile and "The Plague of the Year"). Göttinger Miszellen 49: 77-83.

Wilson P (1997) A Ptolemaic lexikon, A lexicographical study of the texts in the temple of Edfu. Orientalia Lovaniensia Analecta 78. Leuven: Peeters Publishers. 
